\title{
Organizational linkages for new product development: \\ Implementation of innovation projects
}

Teresa Cometto, Universidad Politécnica de Madrid and Universidad ORT Uruguay Arsalan Nisar, University of Neuchâtel

Miguel Palacios, ESCP Europe Business School

Kenneth Le Meunier-FitzHugh, University of East Anglia

Gaston J. Labadie, Universidad ORT Uruguay

Submitted: July 2015

Revised: August 2015

Accepted: October 2015

The authors are grateful to contributions from Felix Roux, Universidad Politécnica de Madrid and Carlos Casanueva, ESCP Europe Business School, whose comments and feedback were helpful in improving and expanding this study. Send correspondence to Teresa Cometto, Facultad de Administración y Ciencias Sociales, Universidad ORT Uruguay, Bulevar España 2633, Montevideo, Uruguay (tcometto@uni.ort.edu.uy); Arsalan Nisar, Chair of Energy and Innovation, Enterprise Institute, Faculty of Economics and Business, University of Neuchâtel, A-L Breguet 2, Neuchâtel 2000 Switzerland (arsalan.shah@unine.ch); Miguel Palacios, ESCP Europe Business School, Madrid Campus, Arroyofresno, 1, Madrid, Spain, (mpalacios@escpeurope.eu); Kenneth Le Meunier-FitzHugh, Norwich Business School, University of East Anglia, Norwich, NR4 7TJ, United Kingdom (k.le-meunier-

fitzhugh@uea.ac.uk); Gaston J. Labadie, Facultad de Administración y Ciencias Sociales, Universidad ORT Uruguay, Bulevar España 2633, Montevideo, Uruguay (labadie@ort.edu.uy). 


\begin{abstract}
Effective external and internal organization linkage characterizes new product development. Although research covers the external linkages to gain operational efficiencies and develop new products, the current body of scholarship on internal cross-functional linkages requires further attention. This study provides a certain level of inquiry into the antecedents of such internal linkages and presents a framework to establish the relationship between two internal functions at a major fast-moving consumer goods (FMCG). The study examines the implementation of 150 innovation projects in 6 different countries over a period of three years. The objective is to study the influence of trust dimension on the perceived effectiveness of cross-functional linkage to highlight how organizational mechanisms like the amount and quality of shared communication affect trust and relationship between two functions.
\end{abstract}

Keywords: Cross-functional linkages; product innovation; research and development; FMCG 


\section{Introduction}

Introducing new products is becoming increasingly challenging in face of hyper competition and ever changing consumer preferences. As a result, the focus on new product development (NPD) is crucial, especially in industries like fast-moving consumer goods (FMCG), which have shorter product life cycles and seasonal demand (Mundra et al., 2013). Most of the prior research on NPD focuses on external linkages as part of supply chain to strengthen operational efficiencies and to collaborate for opportunity recognition leading to new product opportunities (Banker et al., 2006). However, research connecting the antecedents affecting internal linkages across different functions requires further analysis. This study investigates the antecedents of organizational linkages affecting marketing and sales functions during the formalized process of new product development (NPD). According to the literature, marketing and sales interface as an organizational linkage is a key crossfunctional interface to increase customer value and business performance (Guenzi \& Troilo, 2007; Guzmán-Cuevas et al., 2009; Homburg \& Jensen, 2007; Le MeunierFitzHugh \& Piercy, 2007; Lee et al., 2007; Malshe \& Sohi, 2009, Ribeiro-Soriano \& Urbano, 2010). However, most of the empirical research in this direction remains limited and evidence reports poor collaboration between sales and marketing functions (Kotler et al., 2006; Rouziès et al., 2005; Ries \& Ries, 2009) and even research to support inter-functional conflict (Dawes \& Massey, 2005; Le MeunierFitzHugh \& Piercy, 2007).

In this direction, Ernst et al. (2010), and Malshe and Biemans (2014) identify the importance of sales and marketing interaction during new product development to underline the need for a strong relationship between sales and marketing to create organizational success (Guenzi \& Troilo, 2007; Le Meunier-FitzHugh \& Piercy, 
2007; Le Meunier-FitzHugh et al., 2011). Further, Hughes et al. (2012) link sales and marketing operational effectiveness with strong new product capability. Research specifies that interpersonal trust and communication are essential antecedents in establishing collaborative, cross-functional relationships between sales and marketing (e.g., Dawes \& Massey, 2007; Homburg et al., 2008; Hulland et al., 2012).

Nevertheless, no specific studies focus on how organizational linkages between sales and marketing can influence the success of new product development in FMCG subsidiaries.

To address this shortcoming on how to improve the implementation of new product launches in FMCG subsidiaries, this study examines interpersonal trust and communication as factors that can influence interaction between marketing and sales. This study follows a quantitative method at a major FMCG firm operating in six countries. This research examines some of the relevant variables (communication amount, communication quality, cognitive-based trust, affect-based trust, and perceived relationship effectiveness) in six countries for a major FMCG firm, listed in the Global 500 (Global Fortune, 2013). The studied cluster represents an exemplar case of marketing and sales interface, recognized for its excellence in execution of innovation projects for NPD worldwide.

The novelty of the study lies in its focus on the influence of sales and marketing interactions on the implementation of a new product launch. The study explores the impact of communications and trust on the relationship effectiveness between sales and marketing. Because of the successful performance resulting from the implementation of innovation in the market, the study expands the working procedure between marketing and sales presented in this research to other clusters. The main objective of this research is to study the influence of two trust dimensions 
on the perceived effectiveness of marketing/sales relationship during the implementation of innovation projects. The study analyzes how organizational mechanisms, like the amount of shared communication and its quality, affect trust and the relationship of effectiveness between marketing and sales functions. The structure of this study is as follows. Section 2 provides a detailed literature background to establish the hypotheses. Section 3 presents the method and the discussion of the results. Finally, sections 4, 5, and 6 present the conclusions, the relevance of results and their limitations, as well as possible directions for future research.

\section{Background}

Rouziès et al. (2005, p. 115) argue, "Sales-marketing integration is a dynamic process in which the two functional areas create more value for their firms by working together than they would create by working in isolation.” Therefore, activities are consistent and coherent with each other (same goal) and their coordination over time creates a positive relationship between formal and informal communication, and sales and marketing integration.

Recent work in this area suggests that different firms may organize, manage, and reward their sales and marketing functions differently, which may affect interface dynamics (Biemans et al., 2010; Homburg et al., 2008; Malshe, 2010; Malshe \& Sohi, 2009a, inter alia). Research reports a positive association between data dissemination and communication, and new product development (Arnett \& Wittman, 2014; Fisher et al., 1997; Kotler et al., 2006). Empirical evidence suggests that communication in internal relationships can influence trust development (McAllister, 1995) and consequently the model presented links communication directly to interpersonal trust and perceived relationship effectiveness (the dependent variable). 
The model builds on the theoretical foundations of interaction theory (MasVerdú et al. 2015; Moenaert et al., 1994; Ribeiro-Soriano \& Castrogiovanni, 2012; Ribeiro-Soriano \& Roig-Dobón, 2009; Ruekert \& Walker, 1987) and trust (McAllister, 1995). The interaction approach focuses on factors such as trust and communication to predict cross-functional relationships (Ruekert \& Walker, 1987) with the concepts of sales and marketing inter-functional perceived relationship effectiveness (Biemans et al., 2010; Homburg et al., 2008; Kotler et al., 2006). Figure 1 presents the conceptual model that hypothesizes this approach.

Figure 1 here.

\subsection{The perceived effectiveness of the sales-marketing relationship}

The dependent construct is the degree to which sales and marketing managers perceive that the relationship (dynamic process of consistent and coherent activities coordinated over time) is effective in achieving organizational objectives (Dawes \& Massey, 2006). This study operationalizes at the interpersonal level rather than the inter-departmental level, consistent with Ruekert and Walker (1987). In spite of being a psychosocial outcome that managers experience, perceived relationship effectiveness may be an antecedent of objective outcomes like successful innovation, superior value creation, and sales growth or market share (Dawes \& Massey, 2005; Homburg \& Jensen, 2007; Le Meunier-FitzHugh \& Piercy, 2007).

\subsection{Interpersonal trust}

Scholarly literature highlights the importance of interpersonal trust in intraorganizational relationships (Goris et al., 2003). Studies report an association between 
interpersonal trust in teams and a wide range of positive outcomes, such as increased satisfaction within the team and team commitment (Costa, 2003) and knowledge and resource exchange, which in turn enhance team performance (Walumbwa et al., 2011). McAllister (1995) explains that peer managers who personally trust each other experiment a significant increase in sensitivity to each other's personal and workrelated needs. Greater interpersonal trust between managers can improve overall business performance. Trust is especially critical to firms using cross-functional teams to coordinate work, where trust can improve social coordination, formal and informal cooperation, and organizational decision-making (Williams, 2001).

Interpersonal trust's conceptualizations are diverse, but two of the underlying dimensions McAllister (1995) identifies are cognitive-based and affect-based trust. Trust is cognition-based when we choose to interact with people who have previously proved to be professionally competent and reliable on issues related to the job. Affectbased trust creates more emotional ties between individuals when individuals express their concern for personal wellbeing (e.g., the person showing attention and concern for the benefit and wellbeing of people within the team). Previous empirical research establishes that cognitive-based and affect-based trust are distinct (Ganesan \& Hess, 1997) and have different effects on cross-functional working relationships (Goris et al., 2003; McAllister, 1995). Considering that cognitive-based trust refers to perceived peer reliability and professional competence, cognitive-based trust should associate positively with relationship effectiveness. According to McAllister (1995), affect-based trust is more likely to develop with a manager perceived to be competent and reliable, that is, affect-based trust develops from an existing foundation of cognitive-based trust. When affect-based trust develops between sales and marketing managers, they are more likely to perceive a more effective relationship (Dawes \& 
Massey, 2007). Based on prior research, three hypotheses explain the relationship between trust and the perceived relationship effectiveness.

H1. Cognitive-based trust between marketing and sales managers has a positive relation with perceived relationship effectiveness. H2. Cognitive-based trust between marketing and sales managers has a positive relation with affect-based trust. H3. Affect-based trust between marketing and sales managers has a positive relation with perceived relationship effectiveness.

\subsection{The role of inter-functional communication}

Literature on collaboration identifies that effective communication across organizational boundaries is a necessary element to improve interaction, understanding, and goal setting (Hulland et al., 2012; Kotler et al., 2006; Le MeunierFitzHugh \& Piercy, 2007). The aim of increasing communication is to raise joint involvement, thereby helping to establish closer inter-functional relationships (Souder, 1988). Conversely, different studies identify that barriers to inter-functional communications can have negative effects on cross-functional interactions (e.g. Dawes \& Massey, 2005; Rouziès et al., 2005). Hulland et al. (2012) proposes that the amount and quality of communication are important aspects of cross-functional interaction that associate with improved relationship commitment.

Given the importance of cross-functional communication to develop effective and collaborative interaction to achieve functional coordination (Fisher et al., 1997), this study explores two communication dimensions: the amount of communication, and communication quality. Amount of communication is the volume of information exchange between sales and marketing managers through emails, telephone, formal or informal meetings, and reports (Morgan \& Piercy, 1998; Ruekert \& Walker, 1987). 
However, Rouziès et al. (2005) highlight that simply increasing the amount of communication is unlikely to improve cross-functional relationships because such amount of communication can cause conflict and overloading of staff. Further, Dawes and Massey (2005) find that increasing communication eventually reduces relationship effectiveness. One way to improve communication without reducing its effectiveness is establishing bidirectional communications that provide relevant and current information with feedback, leading to a shared conceptualization of the market. This development of quality communication (timely, specific, and relevant) may result from engaging in discussion and feedback. Consequently, this study defines communication quality as the extent to which communication between sales and marketing managers is a bi-directional process of credible and relevant information exchanges (Dawes \& Massey, 2005; Fisher et al., 1997). Becerra and Gupta (2003) observe a positive correlation between communication frequency and perceived trustworthiness of peer managers, while Massey and Kyriazis (2007) confirm that greater communication frequency leads to greater cognitive-based trust in a study of the relationship between R\&D and marketing. H4. Communication amount has a positive association with communication quality between marketing and sales managers. H5. Communication amount has a positive association with cognitive-based trust between marketing and sales managers. H6. Communication amount has a positive association with affect-based trust between marketing and sales managers.

Managers frequently employ bidirectional (consultative) communication to improve cross-functional relationships between sales and marketing departments (Dawes \& Massey, 2005; Rouziès et al., 2005) to help to reduce interdepartmental conflict by aligning targets, improving understanding, and sharing ideas. Bi-directional 
communication enhances social aspects of relationships, hence its relation with affectbased trust (Massey \& Kyriazis, 2007). Fisher et al. (1997) find that bi-directional communication and the perceived marketing-engineering relationship effectiveness have a positive relation during the innovation process. H7. Communication quality has a positive association with cognitive-based trust between marketing and sales managers. H8. Communication quality has a positive association with affect-based trust between marketing and sales managers. H9. Communication quality has a positive association with the perceived relationship effectiveness between marketing and sales managers.

\section{Method}

\subsection{Survey context and data collection}

The study took place at a multinational consumer packaged goods company in six countries (Argentina, Chile, Peru, Bolivia, Uruguay and Paraguay) from 2012 until 2015, involving questionnaires and follow-up confirmatory interviews. Each of the six subsidiaries is significantly large in turnover, with annual sales ranging from $\$ 100$ million to more than $\$ 1$ billion. The company, listed in the Global 500 (Global Fortune, 2013), has a worldwide presence and a large market share for 15 participating categories and 25 different brands.

\subsection{Sample characteristics}

The present study surveyed managers in sales and marketing departments involved in 150 innovation projects of the same firm across the six countries, based on a database supplied by the firm. The data-collection instrument was a selfadministered written questionnaire. Each employee included in all the six countries' 
database (directors, category, channel, and brand managers) received the questionnaire through email during August 2012.

Each person contacted received an introduction on the project's objective, as well as an information confidentiality clause. The questionnaire and its rating scales build on previous literature; the study assessed those scales through semi-structured qualitative interviews. Tests of non-response bias revealed no statistically significant differences between the early and late respondents.

The data based on the interface between marketing and sales within a single company could seem less representative than data collected from different types of firms. However, data collection includes different subsidiaries within the same company, thus providing a complete picture through a census of marketing and sales directors and managers (Ruekert \& Walker, 1987), providing detailed evidence on an exemplar "case". Additionally, a follow-up research took place in 2013, 2014, and 2015 through 18 confirmatory qualitative in-depth interviews with managers in the six countries (Hauser, 1993; Woodside, 2015).

\subsection{Measurement}

The study uses reflective multiple-item, 7-point Likert scales measures (Jarvis et al., 2003) for all the constructs described in the conceptual framework (communication amount, communication quality, cognition-based trust, affect-based trust, and perceived relationship effectiveness).

The items used to assess the amount of communication come from Morgan and Piercy (1988) and the items assessing the quality of communication come from Fisher et al. (1997), Homburg et al. (2008), and Monaert et al. (1992). Although previous research assesses communication frequency through a formative multi-item 
scale, this study uses a reflective multi-item scale for all the constructs. Using reflective scales allows testing the constructs for dimensionality, reliability, and validity. The study assesses cognitive-based trust and affect-based trust using items adapted from McAllister (1995). Perceived relationship effectiveness assessment uses items from Homburg et al. (2008), and Ruekert and Walker (1987). The appendix contains details for each scale. Some items are absent from the study as result of a previous empirical test and in depth interviews to key opinion managers.

\section{Analysis and results}

\subsection{Response rates}

Following a quality control of the data, valid responses amount to 152 from all six countries, over a period of less than 30 days. 55\% of the answers are from marketing, $45 \%$ from sales, $7 \%$ from directors, $33 \%$ from category or channel managers and $60 \%$ from brand or client managers. These cases represent a high response rate of $70 \%$. No significant differences exist between the means of respondents from sales and marketing and from different hierarchical levels. On average, $25 \%$ of the sample is from Argentina, 25\% from Uruguay, 20\% from Peru, and the remaining 16\% equally represents Bolivia and Paraguay. Country origin differences in means are significant for the dependent variable "perceived relationship effectiveness" between marketing and sales. This measurement tool seems sensitive to different levels of structural complexity and evolution, in spite of being part of the same multinational firm with the same corporate guidelines.

\subsection{Descriptive results}


From Table 1, the mean score for perceived relationship effectiveness is 5.26 $(\mathrm{SD}=1.25)$, showing on average a high perceived relationship effectiveness between sales and marketing managers (7-point scales with completely agree/completely disagree anchors). However, the relatively high standard deviation owes to the substantial variation in the quality of the relationship between countries. On average, the amount of interpersonal trust between managers is quite high compared with previous research of R\&D and marketing interface (Massey \& Kyriazis, 2007), cognition-based trust is $5.46(\mathrm{SD}=1.22)$, and affect-based trust is $4.98(\mathrm{SD}=1.22)$.

The communication amount is, on average, considerably high $5.30(\mathrm{SD}=$ 1.45), because of the substantial variation in the frequency of meetings between countries; however, the quality of communication shows on average a lower level $5.07(\mathrm{SD}=1.41)$

\subsection{Measure refinement}

Following exploratory factor analysis, the study reassesses the reliability of each multi-item scale through calculation of the alpha coefficient (without violating minimal sample size to parameter ratios). Table 1 shows that the reliability estimate of amount of communication, although acceptable, is the weakest. The rest of the measures produce acceptable-to-high levels of internal consistency: The results confirm earlier assessments of the dimensions trust (both cognitive and affect based), communication quality, and perceived relationship effectiveness.

Convergent validity results from calculating the average variance extracted (AVE) for each construct that was higher than 0.50 . The study establishes discriminant validity confirming that the correlation for all pairs of constructs is less than the AVE root square for each individual construct (Fornell \& Larcker, 1981). 
Additionally, the study evaluates the pattern of cross-loadings of all items to verify that no item loading is higher in another construct than in the construct that item measures (Chin, 1998).

Table 1 here.

\subsection{Model estimation and testing results}

A confirmatory factor analysis (CFA) assesses the validity of the measures. Two-Stage Least-Squares (2SLS) (Fox, 2006) estimate the model of observed variables through the open software R (Package 2.15.1., R Core Team, 2012). This software considers the sample size without losing precision through a large number of parameters (McCallum \& Austin, 2000). Table 2 shows the resulting indexes indicate construct acceptable fit.

Table 2 here.

The result of $\mathrm{R}^{2}$ for perceived relationship effectiveness is $0.77, \mathrm{R}^{2}$ for cognition-based trust is 0.41 , affect-based trust is 0.36 , communication quality is 0.56 and amount of communication is 0.22 . These findings suggest that the model predicts well the dependent variable and the focal variables - trust cognition and affect based-of this study.

Both forms of trust have a positive relationship with the effectiveness of salesmarketing relationship: cognition-based trust with perceived relationship effectiveness $(\beta=0.369 ; \mathrm{p}<0.01)$, and affect-based trust with perceived relationship effectiveness $(\beta=0.382 ; p<0.01)$. In addition, the results suggest that cognition-based trust has a strong positive effect on affect-based trust $(\beta=0.516 ; \mathrm{p}<0.001)$. Another important finding is that communication quality has a positive relation to the effectiveness of marketing and sales relationship $(\beta=0.526 ; \mathrm{p}<0.01)$. Communication amount has a 
strong positive effect on the quality of communication $(\beta=0.684 ; p<0.001)$. Further, communication quality has a strong positive effect on cognitive-based trust $(\beta=$ 0.692; $\mathrm{p}<0.001)$. However, the following have no significant effect; communication amount on affect-based trust $(\beta=0.036$; n.s.), communication amount on affect-based trust $(\beta=0.223$; n.s. $)$, and communication quality on affect-based-trust $(\beta=0.096$; n.s.). These results suggest that communication amount has no direct effect on trust, but does have an indirect effect through communication quality. However, communication quality has a direct effect on cognitive-based trust, no direct effect on affect-based trust, and an indirect effect through cognitive-based trust.

Table 3 here.

Figure 2 here.

The goodness-of-fit statistics of the model indicate an adequate fit with $\chi 2=$ 224.25, degrees of freedom $(\mathrm{Df})=152 ; \mathrm{p}<0.001(\chi 2 / \mathrm{Df}=1.5), \mathrm{GFI}=0.90$, TuckerLewis index $(\mathrm{NNFI})=0.90$, Comparative fit index $(\mathrm{CFI})=0.96$, and standardized root mean square residual $(\mathrm{SRMR})=0.04$. Particularly, research reports $\mathrm{CFI}$ as a robust index even under severely non-normal conditions (Ping, 1995). The results are consistent with findings resulting from in-depth interviews conducted in subsequent years (2013 and 2014).

\section{Discussion}

\subsection{Research implications}

Despite growing interest in understanding the importance of the marketingsales interface (Homburg \& Jensen, 2007; Rouziès et al., 2005), previous work does not fully explain the role of both constructs of trust in this interface. Previous literature highlights key factors, such as senior management attitudes, integration 
mechanisms, and conflict, which can contribute to hamper the coordination of collaborative sales and marketing relationships (Dawes \& Massey, 2007; Guenzi \& Troilo, 2007; Homburg, et al., 2008; Le Meunier-FitzHugh \& Piercy, 2007; Malshe \& Sohi, 2009a).

The results show that communication amount and quality, and inter-personal trust, have positive effects on perceived relationship effectiveness of marketing and sales relationships in FMCG firms. Both the identified factors of interpersonal trust (cognitive-based and affect-based) have a positive effect on the dependent construct of perceived relationship effectiveness between marketing and sales. Further, previous research (Dawes \& Massey, 2007; McAllister, 1995) finds that cognitive-based trust is a strong predictor of affect-based trust in the relationship between managers from different departments. This finding is significant, because building cognitive-based trust is a necessary foundation to building affect-based trust in this study (McAllister, 1995). These findings support the view that trust can increase team performance.

Consequently, when building teams, managers should focus on facilitating interpersonal trust in both forms.

The amount of communication affects positively communication quality, but only communication quality supports cognitive-based trust and perceived relationship effectiveness. The significant interactional effect of communication quality on cognitive-based trust means that when marketing and sales managers share relevant market information, the mutual perceived competence of marketing and sales increases. This effect stimulates cognitive-based trust, which in turn affects affectbased trust. The current study proposes that quality of communication is an important mediator of communication amount and cognitive-based trust. 
Results fail to support hypotheses 5 and 6. Rouziès et al. (2005) suggest that communication quantity might have an inverted 'U-shaped' relationship with marketing and sales collaboration. This proposition builds on the premise that too much communication becomes obstructive in conveying information, is timeconsuming, and a source of inter-functional conflict. If communication amount has an inverted ' $U$ '-shaped relationship with collaboration between marketing and sales, this may explain why communication amount does not affect directly either of the trust constructs, because too much frequency in communication could indicate insecurity or lack of discrimination in the relationship, which could damage trust. Marketing and sales' creation of relevant and timely information allows information's effective communication (communication quality), thus building cognition-based trust between both departments (marketing and sales).

Additionally, communication quality established during the implementation of innovations should lead to aligned strategies and activities, building greater cognitivebased trust. However, according to the findings, communication quality does not directly relate to affect-based trust (H8). Communication quality should create greater understanding between the parties, which would help to build affect-based, trust. Instead, the findings indicate that cognitive-based trust precedes affect-based trust. Communication quality conveys reliability because this information can depend on creating the environment for greater cognitive-based trust rather than generating affect-based trust. Consequently, the effect of communication quality is twofold; communication quality (1) improves cognitive-based trust and (2) directly affects perceived relationship effectiveness by creating coordination, and increases relationship commitment. The results reveal no significant differences within sales and marketing, not even across director and manager levels. Large FMCG firms tend 
to have a strong differentiation of tasks and activities between marketing and sales; however, the balanced position and power of both departments could explain the lack of significant difference between the variables that explain the perceived relationship effectiveness and other relevant constructs.

\subsection{Managerial implications}

These findings are relevant for firms implementing innovation through marketing and sales cross-functional teams, because the empirical results of the model provide insights into how to improve sales and marketing perceived relationship effectiveness. Further, managers should facilitate both the amount and quality of information flows between sales and marketing staff. This result is relevant because the amount of communication can directly influence communication quality (Hulland

et al., 2012). The proficient communication of market information between marketing and sales can also be instrumental in building interpersonal trust. Therefore, managers should implement systems to stimulate information-sharing (both amount and quality) and reward sales and marketing based on achieving joint objectives (Le MeunierFitzHugh et al., 2011).

\subsection{Limitations and directions for future research}

This study takes place in a consumer goods packaged company in different countries; thus, further research should test the findings' applicability to other industries. A more detailed examination of a larger number of firms, on other taxonomical industries (Homburg et al., 2008), would provide more insightful information on the innovation process. Additionally, a wide range of factors affect cross-functional relationships; therefore, future research could draw on other 
frameworks such as the effect of different "linkage devices" on trust and relationship effectiveness.

From the methodological point of view, limitations come from the assumption of linearity of the structural relations between constructs of the model and the subjective construct - perceived relationship effectiveness — as the outcome. Although previously studied (Hulland et al., 2012; Massey \& Kyriazis, 2007), future work could add objective measures, such as new product turnover, market share, and mix participation. Although this research yields no significant differences between hierarchical levels, further work should focus on lower levels, where more conflicts could arise.

\section{Conclusions}

This study contributes to the understanding of factors that firms may employ to enhance the critical marketing and sales cross-functional relationship in FMCG firms. The twin effects of communication amount and quality operate on the dimensions of interpersonal trust, and directly on the perceived effectiveness of sales and marketing relationships. Further, interpersonal trust influences the perceived effectiveness of sales and marketing relationships. This study examines the effect of the two factors of interpersonal trust on marketing and sales relationship effectiveness and examines the effect of both communication amount and quality on the effectiveness of relationship and as moderators of the trust-perceived relationship effectiveness. Finally, this study is the first quantitative empirical research of drivers affecting the relationship of the sales-marketing interface in emerging market context and contributes to react effectively when confronted to a high turbulence context, capitalizing post-crisis growth by delivering value to consumers and clients. 
In this context, the findings suggest that the main challenge for managers is to make sure marketing and sales teams continue to improve the effectiveness of their relationship, building trust and developing organizational linkages and information sharing mechanisms. Future studies may use other markets and cultural behaviors to validate these findings, or explore additional approaches of this interface. 


\section{References}

Arnett, D., \& Wittman, C. (2014). Improving marketing success: The role of tacit knowledge exchange between sales and marketing. Journal of Business Research, 67(3), 324-331.

Banker, R, Bardhan, I., \& Ozer, A (2006). Understanding the impact of collaboration software on product design and development. Information Systems Research, $17(4), 352-373$

Becerra, M., \& Gupta, A. K. (2003). Perceived trustworthiness within the organization: The moderating impact of communication frequency on trustor and trustee effects. Organization Science, 14(1), 32-44. doi:10.1287/orsc.14.1.32.12815

Biemans, W. G., Brencic, M. M., \& Malshe, A. (2010). Marketing-sales interface configurations in B2B firms. Industrial Marketing Management, 39(2), 183194. doi:10.1016/j.indmarman.2008.12.012

Chin, W. W. (1998). The partial least squares approach to structural equation modeling. In Marcoulides, G. A. (Ed.), Modern methods for business research, 295-336. Mahwah: Lawrence Erlbaum Associates Publishers.

Costa, A. (2003). Work team trust and effectiveness. Personnel Review, 32, 605-622. doi: $10.1108 / 00483480310488360$

Dawes, P. L., \& Massey, G. R. (2005). Antecedents of conflict in marketing's cross functional relationship with sales. European Journal of Marketing, 14(11-12), $1327-1344$.

Dawes, P. L., \& Massey, G. R. (2006). A study of relationship effectiveness between marketing and sales managers in business markets. Journal of Business \& Industrial Marketing, 21(6), 346-360. 
Dawes, P. L., \& Massey, G. R. (2007). Personal characteristics, trust, conflict, and effectiveness in marketing/sales working relationships. European Journal of Marketing, 41(9-10), 1117-1145.

Ernst, H., W. D. Hoyer, \& C. Rübsaamen, C. (2010). Sales, marketing, and researchand development cooperation across new product development stages: Implications for success. Journal of Marketing, 74(5), 80-92.

Fisher, R. J., Maltz, E., \& Jaworski, B. J. (1997). Enhancing communication between marketing and engineering: the moderating role of relative functional identification. Journal of Marketing, 61, 54-70.

Fornell, C., \& Larcker, D. F. (1981). Evaluating structural equation models with unobservable variables and measurement error. Journal of Marketing Research, 18, 39-50.

Fox, J. (2006). Structural equation modelling with the SEM package in R. Structural equation modelling, 13(3), 465-486.

Jarvis, C. B., MacKenzie, S. B., \& Podsakoff, P. M. (2003). A critical review of construct indicators and measurement model misspecification in marketing and consumer research. Journal of Consumer Research, 30(2), 199-218.

Ganesan, S., \& Hess, R. (1997). Dimensions and levels of trust: implications forcommitment to a relationship. Marketing Letters, 8, 439-448.

Global Fortune 500. (2013). Available at: http://money.cnn.com/magazines/fortune/global500/ (accessed 24 November 2013)

Goris, J. R., Vaught, B. C., \& Pettit, J. D. Jr. (2003). Effects of trust in superiors and influence of superiors on the association between individual-job congruence 
and job performance/satisfaction. Journal of Business and Psychology, 17(3), $327-343$.

Guenzi, P., \& Troilo, G. (2007). The joint contribution of marketing and sales to the creation of superior customer value. Journal of Business Research, 60(2), 98107.

Guzmán-Cuevas, J., Cáceres-Carrasco, R., \& Soriano, D. R. (2009). Functional dependence and productive dependence of SMEs. Small Business Economics, $32(3), 317-330$.

Hauser, J. R. (1993). How Puritan-Bennet used the house of quality. Sloan Management Review, 34(3), 61-70.

Homburg, C., \& Jensen, O. (2007). The thought worlds of marketing and sales: which differences make a difference? Journal of Marketing, 71, 124-142.

Homburg, C., Jensen, O., \& Krohmer, H. (2008). Configurations of marketing and sales: a taxonomy. Journal of Marketing, 72(2), 133-154.

Hughes, D.; Le Bon, J. \& Malshe, A. (2012). The marketing-sales interface at the interface: creating market-based capabilities through organizational synergy. Journal of Personal Selling \& Sales Management, 32(1), 57-72.

Hulland, J., Nenkov, G. Y., \& Barclay, D. W. (2012). Perceived marketing-sales relationship effectiveness: a matter of justice. Journal of the Academy of Marketing Science, 40, 450-467. doi:10.1007/s11747-011-0257-2

Kotler, P., Rackham, N., \& Krishnaswamy, S. (2006). Ending the war between sales and marketing. Harvard Business Review, 84(7-8), 68-78.

Le Meunier-FitzHugh, K., \& Piercy, N. F. (2007). Does collaboration between sales and marketing affect business performance? Journal of Personal Selling \& Sales Management, 27(3), 207-220. 
Le Meunier-FitzHugh, K., Massey, G. R., \& Piercy, N. F. (2011). The impact of aligned rewards and senior manager attitudes on conflict and collaboration between sales and marketing. Industrial Marketing Management, 40(7), 11611171.

Lee, S. M., Ribeiro, D., Olson, D. L., \& Roig, S. (2007). The importance of the activities of service business in the economy: welcome to the Service Business. An International Journal. Service Business, 1(1), 1-5.

Malshe, A., \& Biemans, W. (2014). The role of sales in NPD: an investigation of the U.S. health-care industry. Journal of Product Innovation Management, 31(4): $664-679$.

Malshe, A. (2010). How is marketers' credibility construed within the salesmarketing interface? Journal of Business Research, 63(1), 13-19.

Malshe, A., \& Sohi, R. S. (2009a). What makes strategy making across the salesmarketing interface more successful? Journal of the Academy of Marketing Science, 37(4), 400-421. doi: 10.1007/s11747-009-0132-6

Magnusson, P., Peterson, R., \& Westjohn, S. A. (2014). The influence of national cultural values on the use of rewards alignment to improve sales collaboration. International Marketing Review, 31(1), 30-50.

Mas-Verdú, F., Ribeiro-Soriano, D., \& Roig-Tierno, N. (2015). Firm survival: The role of incubators and business characteristics. Journal of Business Research, 68(4), 793-796.

Massey, G. R., \& Kyriazis, E. (2007). Interpersonal trust between marketing and R\&D during new product development projects. European Journal of Marketing, 41(9-10), 1146-1172. doi: 10.1108/03090560710773381. 
McAllister, D. J. (1995). Affect- and cognition-based trust as foundations for interpersonal cooperation in organizations. Academy of Management Journal, 38(1), 24-59. doi:10.2307/256727

MacCallum, R. C. and J. T. Austin. 2000. Applications of structural equation modeling in psychological research. Annual Review of Psychology, 51, 201226

Moenaert, R. K., Souder, W. E., DeMeyer, A., \& Deschoolmeester, D. (1994). R\&D marketing integration mechanisms, communication flows, and innovation success. Journal of Product Innovation Management, 11, 31-45.

Moenaert, R. K., Deschoolmeester, D., De Meyer, A., \& Souder, W. E. (1992). Information styles of marketing and $\mathrm{R} \& \mathrm{D}$ personnel during technological product innovation projects. $R \& D$ Management, 22(1), 21-39.

Morgan, N. A., \& Piercy, N. F. (1998). Interactions between marketing and quality at the SBU level: influences and outcomes. Journal of Academy of Marketing Science, 26(3), 190-208.

Mundra, N., Gulati, K., \& Gupta, R. (2013). The persona of knowledge management in new product development: Manifestation from FMCG companies. IUP Journal of Knowledge Management, 11(1), 24-37.

Oliva, R. (2006). The three key linkages: improving the connections between marketing and sales. Journal of Business \& Industrial Marketing, 21(6), 395398.

Piercy, N. F., \& Lane, N. (2003). Transformation of the traditional sales force: imperatives for intelligence, interface and integration. Journal of Marketing Management, 19(7), 563-582. 
Ribeiro-Soriano, D., \& Castrogiovanni, G. J. (2012). The impact of education, experience and inner circle advisors on SME performance: insights from a study of public development centers. Small Business Economics, 38(3), 333349.

Ribeiro-Soriano, D., \& Roig-Dobón, S. (2009). Linking globalization of entrepreneurship in small business organizations. Small Business Economics, $32(3), 233-239$.

Ribeiro-Soriano, D., \& Urbano, D. (2010). Employee-organization relationship in collective entrepreneurship: an overview. Journal of Organizational Change Management, 23(4), 349-359.

Ries, A., \& Ries, L. (2009). War in the boardroom: Why left-brain management and right-brain marketing don't see eye-to-eye--and what to do about it. Harper Business

Rouziès, D., Anderson, E., Kohli, A. K., Michaels, R. E., Weitz, B.A., \& Zoltners, A.A. (2005). Sales and marketing integration: a proposed framework. Journal of Personal Selling \& Sales Management, 25(2), 113-122.

Ruekert, R.W., \& Walker, O.C. (1987). Marketing's interaction with other functional units: a conceptual framework and empirical evidence. Journal of Marketing, $51,1-19$.

Walumbwa, F. O., Luthans, F., Avey, J. B., \& Oke, A. (2011). Authentically leading groups: the mediating role of collective psychological capital and trust. Journal of Organizational Behavior, 32, 4-24. doi:10.1002/job.653

Williams, M. (2001). In whom we trust: Group membership as an affective context for trust development. Academy of Management Review, 26(3), 377-396. 
Woodside, A.G. (2015). The good practices manifesto: Overcaming bad practices pervasive in current research in business. Boston College

Xie, J., Song, M., \& Stringfellow, A. (2003). Antecedents and consequences of goal incongruity on new product development in five countries; a marketing view. Journal of Innovation Management, 20, 233-250. 
Table 1. Means, standard deviations, correlations, and internal consistency of constructs

\begin{tabular}{|c|c|c|c|c|c|c|c|c|c|}
\hline \multirow[b]{2}{*}{ Construct } & \multicolumn{4}{|c|}{ Internal consistency } & \multicolumn{5}{|c|}{ Correlations of constructs } \\
\hline & $\begin{array}{l}\mathrm{N}^{\mathrm{o}} \text {. of } \\
\text { items }\end{array}$ & Mean & S.D. & $\alpha$ & $\mathrm{CA}$ & CQ & CBT & $\mathrm{ABT}$ & PRE \\
\hline $\begin{array}{l}\text { Communication } \\
\text { Amount (CA) }\end{array}$ & 3 & 5.30 & 1.45 & 0.73 & 0.80 & & & & \\
\hline $\begin{array}{l}\text { Communication } \\
\text { Quality (CQ) }\end{array}$ & 3 & 5.07 & 1.41 & 0.89 & $0.57 * * *$ & 0.87 & & & \\
\hline $\begin{array}{l}\text { Cognition-based } \\
\text { trust (CBT) }\end{array}$ & 3 & 5.46 & 1.22 & 0.90 & $0.46^{*}$ & $0.62 * * *$ & 0.81 & & \\
\hline $\begin{array}{l}\text { Affect-based trust } \\
\text { (ABT) }\end{array}$ & 3 & 4.98 & 1.22 & 0.81 & $0.51 * *$ & $0.59 * *$ & $0.72 * * *$ & 0.79 & \\
\hline $\begin{array}{l}\text { Perceived } \\
\text { relationship } \\
\text { effectiveness } \\
\text { (PRE) }\end{array}$ & 8 & 5.26 & 1.25 & 0.91 & $0.65 * *$ & $0.70 * * *$ & $0.76^{* *}$ & $0.76^{* *}$ & 0.80 \\
\hline AVE & & & & & 0.50 & 0.76 & 0.66 & 0.62 & 0.60 \\
\hline
\end{tabular}

Note. Significance levels for two-tailed t-tests: $\# \mathrm{p}<0.1 ;{ }^{*} \mathrm{p}<0.05 ;{ }^{*} \mathrm{p}<0.01 ;{ }^{* * *} \mathrm{p}$ $<0.001$

Diagonal elements are the square root of the average variance extracted (AVE) ${ }^{1 / 2}$ 
Table 2. Uni-dimensionality assessment: fit measures for the confirmatory factor analysis

\begin{tabular}{lccccc}
\hline \multicolumn{1}{c}{ Construct } & $\chi^{2} /(\mathrm{D} f)$ & GFI & Tucker-Lewis & Bentler & \\
& & & NNFI & CFI & SRMR \\
\hline Communication Amount (CA) & 0 & 1 & & 0 & 0 \\
Communication Quality (CQ) & 0 & 1 & & 0 & 0 \\
Cognitive-based Trust (CBT) & 1 & 0.91 & 0.91 & 0.92 & 0.05 \\
Affect-based Trust (ABT) & 0 & 1 & & 0 & \\
Perceived Relationship Effectiveness (PRE) & 2 & 0.93 & 0.94 & 0.94 & 0.04 \\
\hline
\end{tabular}

Note. SRMR = standardized root mean square residual, GFI = goodness-of-fit index, $\mathrm{NNFI}=$ non-normed fit index, $\mathrm{CFI}=$ comparative fit index 
Table 3. Marketing and Sales construct relationship, path coefficient, t-values and structural modelling results

\begin{tabular}{|c|c|c|c|c|c|c|c|c|}
\hline $\begin{array}{l}\text { Hypothesized } \\
\text { Relationships }\end{array}$ & $\begin{array}{c}\text { Standard } \\
\beta\end{array}$ & $\mathrm{t}$-value & $x^{2}$ & $d f$ & GFI & $\begin{array}{l}\text { Tucker- } \\
\text { Lewis } \\
\text { NNFI }\end{array}$ & $\begin{array}{l}\text { Bentler } \\
\text { CFI }\end{array}$ & SRMR \\
\hline $\mathrm{H} 1 \mathrm{CBT} \rightarrow \mathrm{PRE}$ & 0.369 & $2.422 * *$ & & & & & & \\
\hline $\mathrm{H} 2 \mathrm{CBT} \rightarrow \mathrm{ABT}$ & 0.516 & $4.126^{* * *}$ & & & & & & \\
\hline $\mathrm{H} 3 \mathrm{ABT} \rightarrow \mathrm{PRE}$ & 0.382 & $3.242 * *$ & & & & & & \\
\hline $\mathrm{H} 4 \mathrm{CA} \rightarrow \mathrm{CQ}$ & 0.684 & $1.009 * * *$ & & & & & & \\
\hline $\mathrm{H} 5 \mathrm{CA} \rightarrow \mathrm{CBT}$ & 0.036 & 0.204 n.s. & & & & & & \\
\hline $\mathrm{H} 6 \mathrm{CA} \rightarrow \mathrm{ABT}$ & 0.223 & 1.511 n.s. & & & & & & \\
\hline $\mathrm{H} 7 \mathrm{CQ} \rightarrow \mathrm{CBT}$ & 0.692 & $4.251^{* * *}$ & & & & & & \\
\hline $\mathrm{H} 8 \mathrm{CQ} \rightarrow \mathrm{ABT}$ & 0.096 & 0.689 n.s. & & & & & & \\
\hline H9 CQ $\rightarrow$ PRE & 0.526 & $2.666^{* *}$ & & & & & & \\
\hline Model statistics & & & $224.25 * * *$ & 152 & 0.90 & 0.95 & 0.96 & 0.04 \\
\hline $\mathrm{R}^{2}$ for PRE & 0.77 & & & & & & & \\
\hline $\mathrm{R}^{2}$ for $\mathrm{CBT}$ & 0.41 & & & & & & & \\
\hline $\mathrm{R}^{2}$ for $\mathrm{ABT}$ & 0.36 & & & & & & & \\
\hline $\mathrm{R}^{2}$ for $\mathrm{CQ}$ & 0.56 & & & & & & & \\
\hline $\mathrm{R}^{2}$ for $\mathrm{CA}$ & 0.22 & & & & & & & \\
\hline
\end{tabular}

Note. Significance levels for two-tailed t-tests: ${ }^{*} \mathrm{p}<0.05 ; * * \mathrm{p}<0.01 ; * * * \mathrm{p}<0.001$ 
Figure 1. Hypothesized Conceptual Model

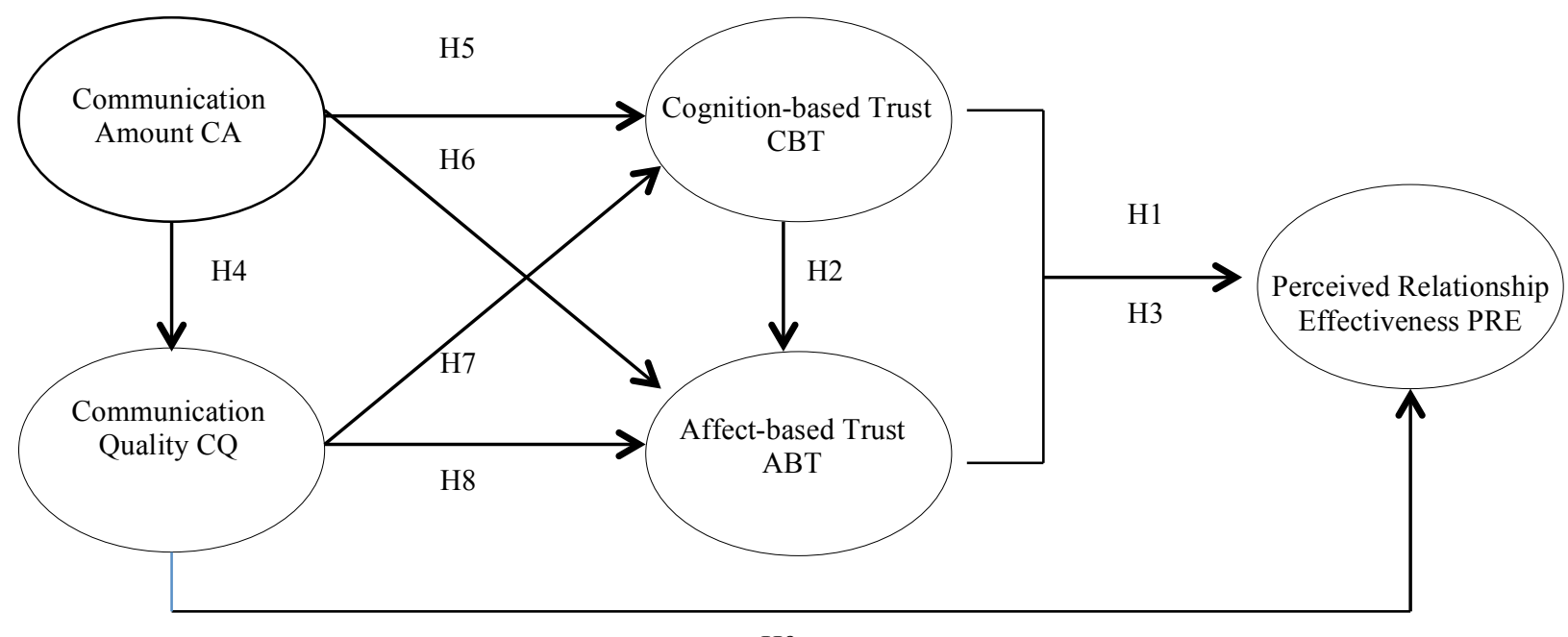

H9

$\mathrm{CA}=$ Communication Amount; $\mathrm{CQ}=$ Communication Quality; $\mathrm{CBT}=$ Cognition-based Trust; $\mathrm{ABT}=\mathrm{Affective}-$ based Trust and PRE=Perceived Relationship Effectiveness 
Figure 2. Structural Model

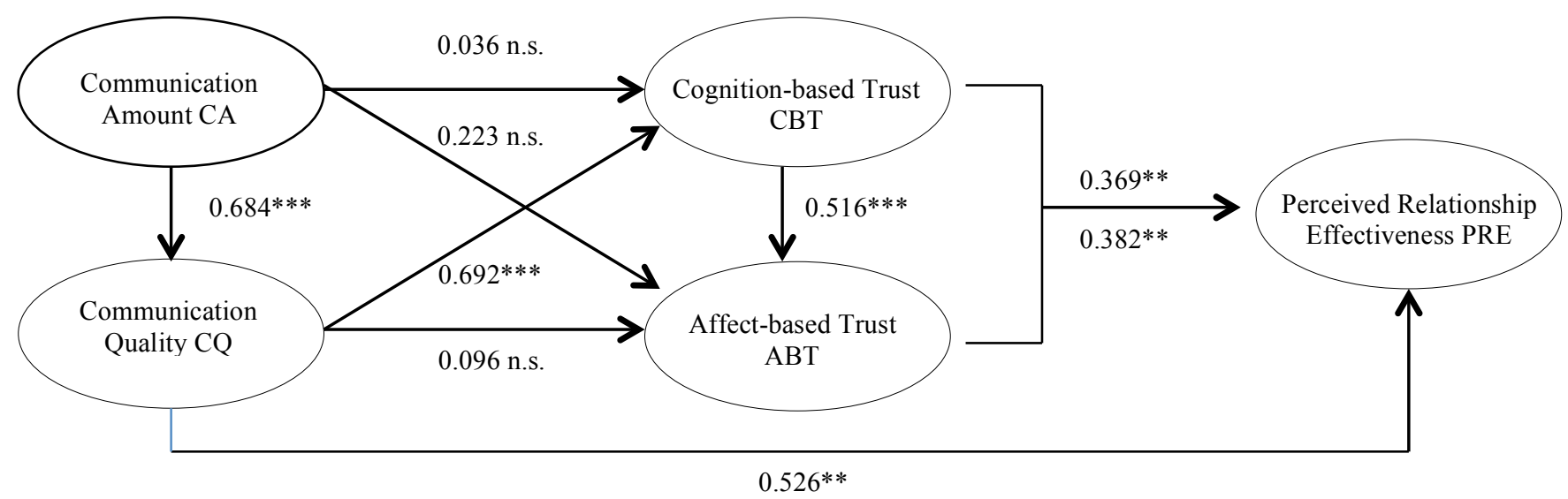

$\mathrm{CA}=$ Communication Amount; $\mathrm{CQ}=$ Communication Quality; $\mathrm{CBT}=$ Cognition-based Trust; $\mathrm{ABT}=\mathrm{Affective-based} \mathrm{Trust}$ and $\mathrm{PRE}=$ Perceived Relationship Efficiency 
Appendix 1. Measurement items by construct

\begin{tabular}{|c|c|c|}
\hline Construct & $\begin{array}{l}\text { Items } \\
\text { (7-point scales with completely agree/completely } \\
\text { disagree anchors) }\end{array}$ & $\begin{array}{l}\text { Measurement } \\
\text { Source }\end{array}$ \\
\hline $\begin{array}{l}\text { Communicatio } \\
\text { n amount (CA) }\end{array}$ & $\begin{array}{l}\text { Generally, in coordinating innovation deployment } \\
\text { the frequency of communication is appropriate } \\
\text { through: } \\
\text { 1.Electronic mail }{ }^{\mathrm{a}} \\
\text { 2.Impromptu face-to face conversations } \\
\text { 3.Scheduled one-to-one phone conversations } \\
\text { 4.Scheduled one-to-one meetings } \\
\text { 5.Impromptu one-to-one meetings } \\
\text { 6.Impromptu one-to-one phone conversations } \\
\text { 7.Reports }\end{array}$ & $\begin{array}{l}\text { Morgan \& } \\
\text { Piercy (1998) }\end{array}$ \\
\hline $\begin{array}{l}\text { Communicatio } \\
\text { n quality (CQ) }\end{array}$ & $\begin{array}{l}\text { Generally, in coordinating innovation deployment, } \\
\text { people in the sales (marketing) unit of our business } \\
\text { unit/company: } \\
\text { 1.Are willing to deal with information request from } \\
\text { marketing (sales) people } \\
\text { 2.Respond promptly and without a reminder to two- } \\
\text { way information requests from marketing (sales) } \\
\text { people } \\
\text { 3.Inform the marketing (sales) unit proactively }{ }^{\mathrm{a}} \\
\text { 4. Provide useful two-way information for } \\
\text { marketing (sales) work on this project } \\
\text { 5. Are very satisfied with the two-way content of } \\
\text { the information provided by marketing (sales) on } \\
\text { this project } \\
\text { 6.Are very satisfied with the relevance of the } \\
\text { information provided by marketing (sales) on this } \\
\text { project }^{\mathrm{a}} \\
\text { 7. Are very satisfied with the form and presentation } \\
\text { of the information provided by marketing (sales) }^{\mathrm{a}}\end{array}$ & $\begin{array}{l}\text { Fisher, Maltz } \\
\text { \& Jaworski } \\
\text { (1997) } \\
\text { Homburg, } \\
\text { Jensen \& } \\
\text { Krohmer } \\
\text { (2008) } \\
\text { Monaert et al. } \\
\text { (1992) }\end{array}$ \\
\hline $\begin{array}{l}\text { Cognitive- } \\
\text { based trust } \\
\text { (CBT) }\end{array}$ & $\begin{array}{l}\text { Generally, in coordinating innovation deployment, } \\
\text { people in the sales (marketing) unit of our business } \\
\text { unit/company: } \\
\text { 1. Other work associates who must interact } \\
\text { considers marketing (sales) to be trustworthy } \\
\text { 2. Marketing (sales) approach their job with } \\
\text { professionalism and dedication } \\
\text { 3. I see no reason to doubt marketing (sales) } \\
\text { competence and preparation for the job } \\
\text { 4. I can rely on marketing (sales) to not make my } \\
\text { job more difficult by careless work }\end{array}$ & $\begin{array}{l}\text { McAllister } \\
(1995)\end{array}$ \\
\hline $\begin{array}{l}\text { Affect-based } \\
\text { trust (ABT) }\end{array}$ & $\begin{array}{l}\text { Generally, in coordinating innovation deployment, } \\
\text { people in the sales (marketing) unit of our business } \\
\text { unit/company: } \\
\text { 1. Have a relationship in which marketing (sales) } \\
\text { both freely share ideas, feelings, and hopes }\end{array}$ & $\begin{array}{l}\text { McAllister } \\
(1995)\end{array}$ \\
\hline
\end{tabular}




\begin{tabular}{|c|c|c|}
\hline & $\begin{array}{l}\text { 2. Can talk openly to marketing (sales) about } \\
\text { difficulties that I'm having at work and know they } \\
\text { will want to listen } \\
\text { 3. If I shared my problems with marketing (sales), I } \\
\text { know that they would respond constructively and } \\
\text { with understanding }\end{array}$ & \\
\hline $\begin{array}{l}\text { Perceived } \\
\text { relationship } \\
\text { effectiveness } \\
\text { (PRE) }\end{array}$ & $\begin{array}{l}\text { Generally, in coordinating innovation deployment, } \\
\text { people in the sales (marketing) unit of our business } \\
\text { unit/company: } \\
\text { 1. Overall, both are satisfied with the working } \\
\text { relationship between marketing and sales } \\
\text { 2. Collaborate frictionless } \\
\text { 3. Act in concert } \\
\text { 4. Coordinate the market-related activities in a } \\
\text { credible way } \\
\text { 5. Fully carried out their responsibilities and } \\
\text { commitments to marketing (sales) } \\
6 \text {. Responded well to feedback and advice from } \\
\text { marketing (sales) } \\
\text { 7. The time spent developing and maintaining the } \\
\text { relationship with marketing (sales) has been } \\
\text { worthwhile } \\
\text { 8. Achieve their common goals } \\
\text { 9. From a performance perspective, the relationship } \\
\text { between marketing and sales has been effective }\end{array}$ & $\begin{array}{l}\text { Homburg, } \\
\text { Jensen, \& } \\
\text { Krohmer } \\
(2008) \\
\text { Ruekert \& } \\
\text { Walker (1987) }\end{array}$ \\
\hline
\end{tabular}

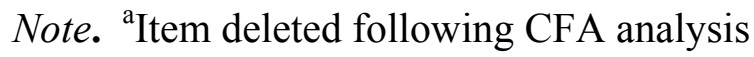

